$9^{\text {th }}$ International Kimberlite Conference Extended Abstract No. 9IKC-A-00165, 2008

\title{
Clinopyroxene-phlogopite rock xenoliths: geochemistry, isotopy, age, origin and relationship to Grib pipe kimberlites (Arkhangelsk province)
}

\author{
Liudmila I. Sablukova and Sergey M. Sablukov
}

RUSGEO Ltd, Moscow, Russia,

The Grib pipe is characterized by a high concentration, large size and relatively weak secondary alteration of mantle xenoliths. The xenoliths are dominated by garnet peridotite and pyroxenite nodules (related to different depth facies), and ilmenite peridotite and eclogite xenoliths are also abundant.

A particular group of ultramafic rocks xenoliths includes numerous xenoliths of inferredly metasomatic, predominantly clinopyroxene-phlogopite rocks. This group is sharply predominanted by glimmerite (phlogopite-containing, clinopyroxene-phlogopite and olivine-phlogopite varieties) and phlogopite clinopyroxenite. Some of these rocks contain moderate amounts of ilmenite, rutile, chrome spinel or pyrope. The texture of these rocks varies from fine-grained to coarse-grained, allotriomorphic, hypidiomorphic, panidiomorphic, poikilitic and, rarely, graphic. The structure of the rocks is generally heterogenous, occasionally taxitic.

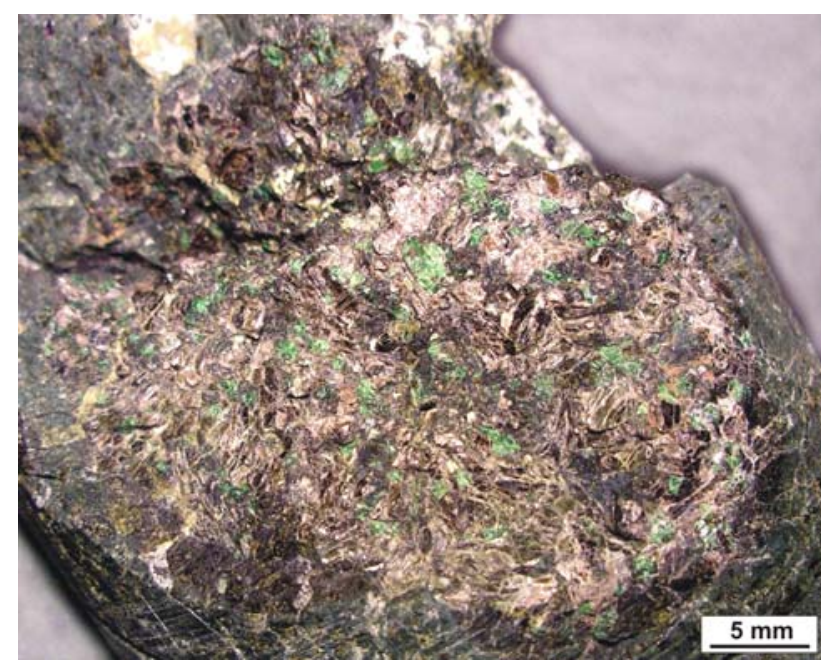

Xenolith of the clinopyroxene-phlogopite glimmerite

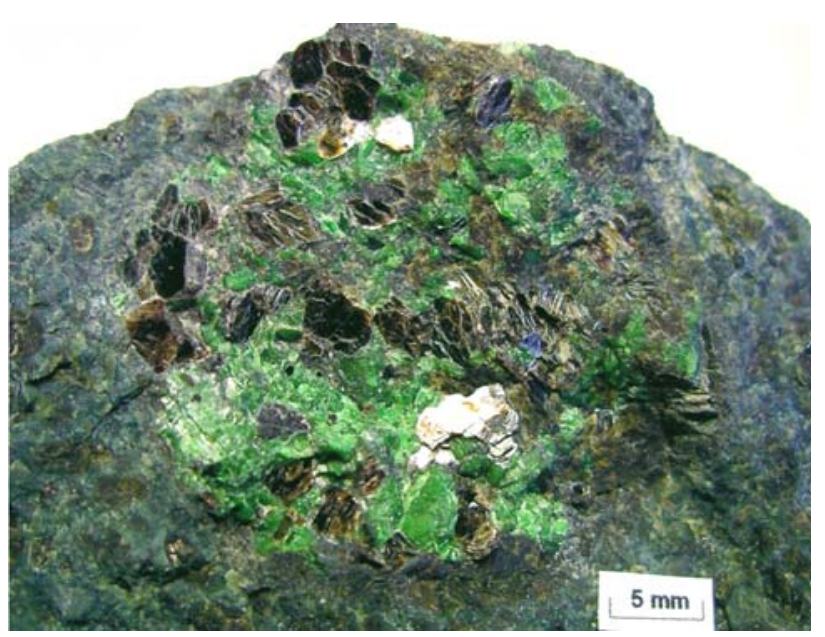

Xenolith of the phlogopite clinopyroxenite

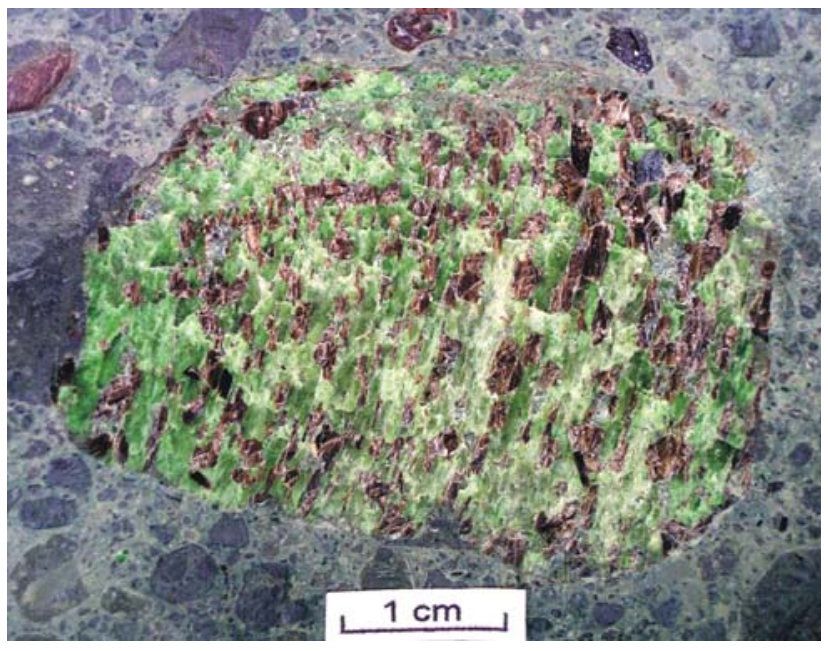

Xenolith of the clinopyroxene-phlogopite symplectite 


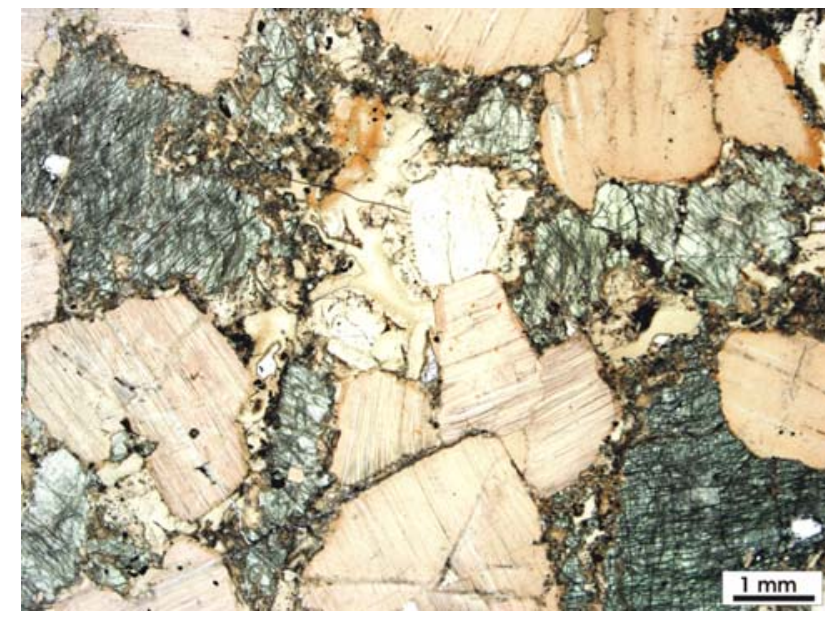

Xenolith of the phlogopite clinopyroxenite: think section. Polarized light.

Geochemically, the clinopyroxene-phlogopite rocks are characterized by a high $\mathrm{Mg}$ index $\left(\mathrm{K}_{\mathrm{mg}}=90.1\right)$, low to moderate concentrations of incompatible elements (except for $\mathrm{K}$ and $\mathrm{Rb}$ ), a high $(\mathrm{La} / \mathrm{Yb})_{\mathrm{N}}$ ratio $(75.9)$, a small negative Eu peak and a strong positive $\mathrm{Rb}, \mathrm{K}, \mathrm{Sr}$, $\mathrm{P}, \mathrm{Ti}, \mathrm{Y}$ and Ga peaks.

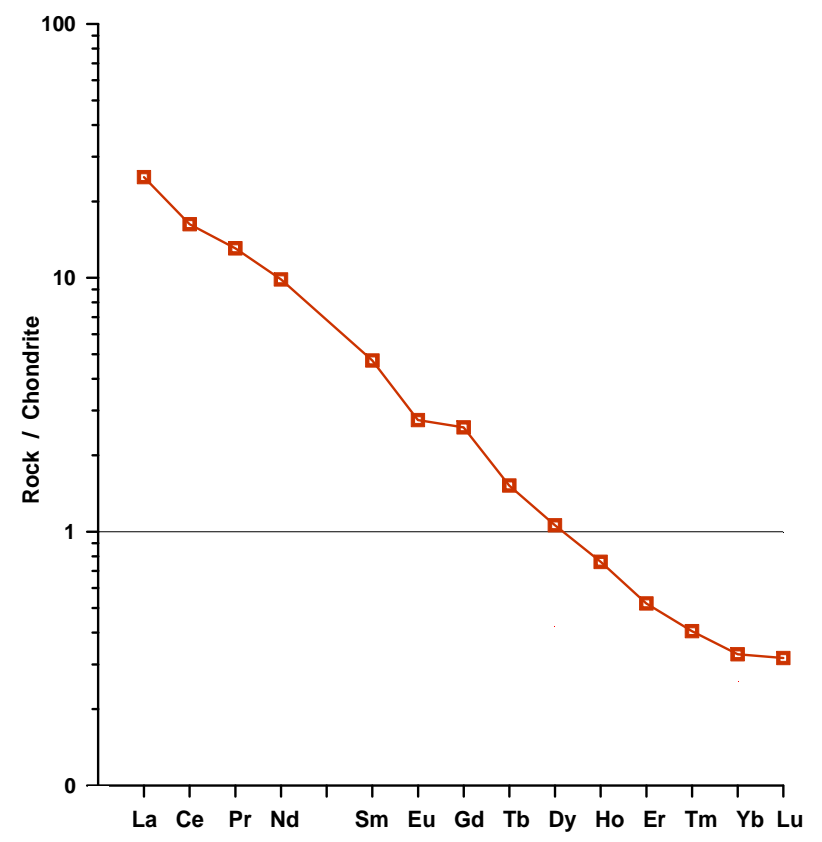

Chondrite normalized REE distribution patterns for phlogopite clinopyroxenite xenoliths (Boynton, 1984).

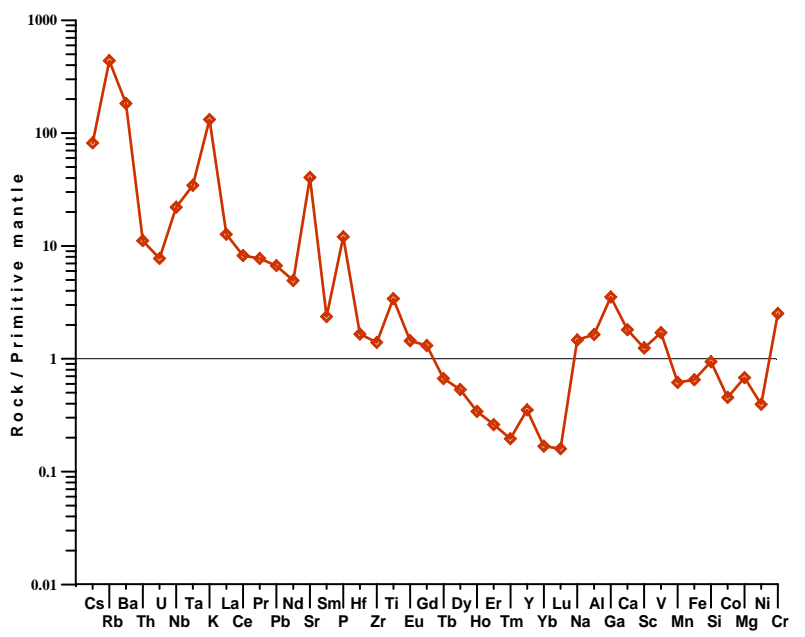

Primitive mantle normalized element composition of volcanic rocks from Juina area, after McDonough et al. (1992) and Jagoutz et al. (1979).

$\mathrm{Rb}$-sr dating established a Late Devonian age for two clinopyroxene-phlogopite rock samples (isochrone age $372.1 \pm 4.7 \quad \mathrm{Ma}, \quad \mathrm{N}=4$, initial ${ }^{87} \mathrm{Sr} /{ }^{86} \mathrm{Sr}=$ $0.70550 \pm 0.00240 ; \quad \mathrm{MSWD}=7.5$ ), which agrees perfectly with the $\mathrm{Rb}-\mathrm{Sr}$ isochrone age of Grib pipe kimberlites (isochrone age $373.1 \pm 5.1 \mathrm{Ma}, \mathrm{N}=4$, initial $\left.{ }^{87} \mathrm{Sr} /{ }^{86} \mathrm{Sr}=0.70452 \pm 0.00013 ; \mathrm{MSWD}=1.6\right)$. The type and model ages of mantle source determined for clinopyroxene-phlogopite rock samples $(\mathrm{N}=2$, $\mathrm{T}_{\mathrm{Nd}}(\mathrm{DM})=840 \mathrm{Ma} ; \mathrm{T}_{\mathrm{Nd}}(\mathrm{CHUR})=200 \mathrm{Ma} ; \varepsilon \mathrm{Nd}=$ $+2.2, \varepsilon \mathrm{Sr}=+56.4)$ also proved to be close to those of Grib pipe kimberlites $\left(\mathrm{N}=7, \mathrm{~T}_{\mathrm{Nd}}(\mathrm{DM})=940 \mathrm{Ma}\right.$; $\left.\mathrm{T}_{\mathrm{Nd}}(\mathrm{CHUR})=370 \mathrm{Ma}\right)$.

In general, the abundance of clinopyroxene-phlogopite rock xenoliths may be evidence of intense water-calcalkali (K-Ca) metasomatism in deep-seated parental substrate rocks for Grib pipe kimberlites. However, the lack of any visible evidence for substitution of a priory primary mantle rock minerals by clinopyroxene and phlogopite, along with the presence of characteristic deformed clinopyroxene and phlogopite grains with fracture bands or "pseudo-twinning" along three cleavage joint systems, when considered together with the fact that the essential minerals in the analyzed rocks are similar in composition to respective primary mantle mineral species (Sablukova et al., 2003), suggest that at least some of the examined clinopyroxene-phlogopite rocks may be of primary magmatic rather than metasomatic origin. 


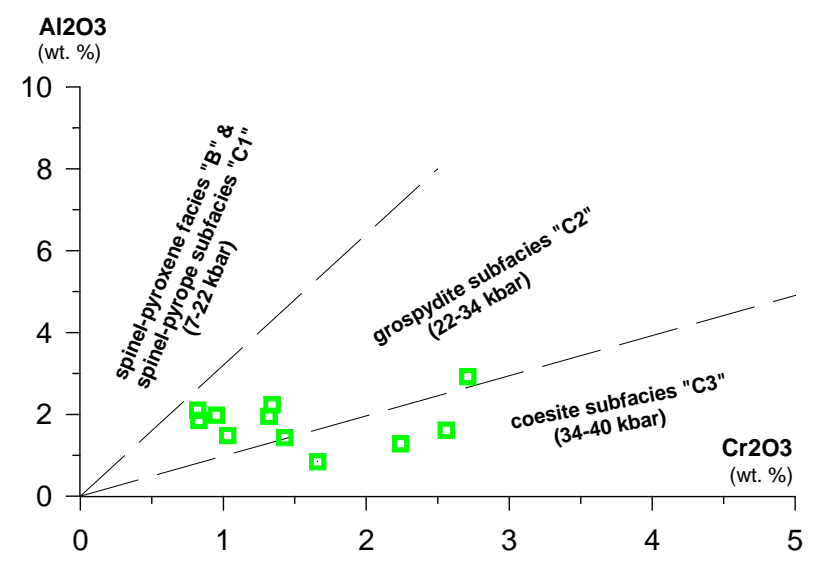

Chemical composition of clinopyroxene from phlogopite clinopyroxenite xenoliths (Sablukov et al., 2000 and Sobolev et al., 1972).

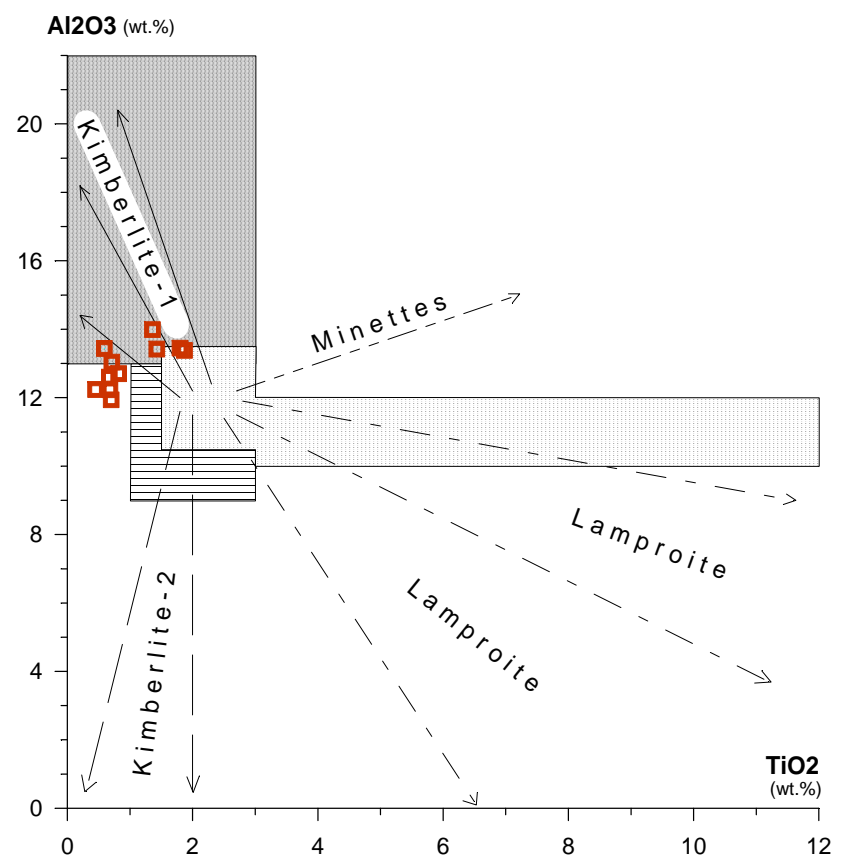

Chemical composition of phlogopite from phlogopite clinopyroxenite xenoliths (Mitchell, 1995).

These rocks could emerge from residual mantle melts (enriched with volatile components) to form vein-type bodies akin to pegmatite and lamprophyre formations in apical parts of crustal intrusions. Judging from the calculated TP parameters $\left(945^{\circ} \mathrm{C}, 33.9 \mathrm{kbar}\right.$, garnet + clinopyroxene mineral suite), clinopyroxenephlogopite rocks of this type might have formed at a depth 100-110 km, which corresponds to grospydite depth subfacies. The finding (sole as yet) of a sharp "cold" contact between the rock of this type and garnet peridotite appears to support the hypothesis of veintype intrusion for these rocks.
Judging from mineralogical and isotope data, the formation of the examined clinopyroxene-phlogopite rocks immediately preceded the intrusion of Grib pipe kimberlites.

\section{References}

Boynton W.V., 1984. Geochemistry of the rare earth elements: meteorite studies. In: Henderson P. (ed.), Rare earth element geochemistry. Elsevier, 63-114.

Jagoutz, T., Palme, H., Baddenhausen, H. et al., 1979. The abundance's and trace elements in the earth mantle as derived from primitive ultramafic nodules.// Proc. X Lunar Planet. Sci. Conf., 2031-2050.

McDonough W.F., Sun S., Ringwood A.E., Jagoutz E. and Hofman A.W., 1992. K, Rb, and Cs in the earth and moon evolution of the earth's mantle. Gejchi. Cosmochim. Acta, Ross Taylor. Symposium.

Mitchell, R.H., 1995. Compositional variation of micas in kimberlites, orangeites, lamproites and lamprophires. Extended Abstracts $6 \mathrm{IKC}$, Novosibirsk, Russia, 390-392.

Sablukov, S.M., Sablukova, L.I. and Shavirina, M.V., 2000. Mantle xenoliths in the Zimny Bereg kimberlite deposits of rounded diamonds, Arkhangelsk diamondiferous province. Petrologiya, 8(5), 466-494.

Sablukova L.I., Sablukov S.M., Verichev E.M. and Golovin N.N., 2003. Petrography and mineral chemistry of mantle xenoliths and xenocrysts from the Grib pipe, Zimny Bereg area, Russia // Proceedings of International Workshop «Plumes and problems of deep sources of alkaline magmatism», Khabarovsk, 65-95

Sobolev, V.S, Dobretsov, N.L. and Sobolev, N.V., 1972. Classification of the deep-seated xenoliths and types of the upper mantle. Geol. and Geoph.12, 37-42 (in Russian). 